\title{
Urban Population Resettlement in the Arctic Zone of Russia*
}

\author{
Viktor Fauzer \\ Institute of Socio-economic and Energy Problems of the \\ North \\ Komi Science Centre Ural Branch of the Russian Academy \\ of Sciences \\ Syktyvkar, Russia \\ E-mail: fauzer@iespn.komisc.ru \\ Lyubov Kuratova \\ Institute of Socio-economic and Energy Problems of the \\ North \\ Komi Science Centre Ural Branch of the Russian Academy \\ of Sciences \\ Syktyvkar, Russia \\ E-mail: lyubov_kuratova@list.ru
}

\begin{abstract}
The article is devoted to the theoretical problems of population resettlement in the Arctic zone of the Russian Federation. It shows the changes in the settlement system in the 2000s. A grouping of settlements according to the number of inhabitants is carried out. The main attention is paid to thestudy of the urban population dynamics in the Arctic. The statistical material of population censuses for 1959-2010 and the data of the current population accounting at the beginning of 2017 are given.
\end{abstract}

Keywords-Arctic; resettlement; urban population

\section{INTRODUCTION}

The Arctic zone of the Russian Federation has an area of about $9 \mathrm{mln} \mathrm{km} 2$. More than 2,5 million people, including indigenous peoples, live here. At the same time, 12-15\% of the Russia's GDP is created in the Arctic zone. About a quarter of Russia's exports are provided. Russia's economic interest in the Arctic lies in the fact that it is viewed as a source of resources for the country's socio-economic development. The scale of economic activity of the Russian Arctic zone significantly exceeds the performance of other polar countries. The share of the added value of extractive industries and enterprises is about 60\%. This indicator in Greenland, Norway, Sweden, Finland, Iceland is for about $15 \%$, in Alaska and in the Arctic Canada - about 30\%. The first place in the structure of the economy is occupied by the gas complex. More than $80 \%$ of Russian gas is produced in the Arctic zone.

* The reported study was funded by RFBR according to the research project № 16-03-00078

\author{
Tatyana Lytkina \\ Institute of Socio-economic and Energy Problems of the \\ North \\ Komi Science Centre Ural Branch of the Russian Academy \\ of Sciences \\ Syktyvkar, Russia \\ E-mail: tlytkina@yandex.ru \\ Galina Fauzer \\ Institute of Socio-economic and Energy Problems of the \\ North \\ Komi Science Centre Ural Branch of the Russian Academy \\ of Sciences \\ Syktyvkar, Russia \\ E-mail: gfauzer@iespn.komisc.ru
}

In recent years, there have been well-founded fears about the lack of population and unreasoned resettlement policy in the regions of the North and the Arctic. For a country with such a vast sparsely populated territory, which has enormous natural resources, the population resettlement is of great importance. Deterioration of population resettlement often occurs due to ill-considered management decisions. Therefore in Russia it is necessary to direct efforts and means for increase of a population level of territory and improvement of settlements scattered across the vast expanses. This primarily concerns the land territories of the Arctic, where it is necessary to create a living environment for the adequate role of the Arctic in the economic and geopolitical interests of Russia.

In our works, various aspects of population resettlement in the northern regions of Russia are described[1] [2]. Studies on the population resettlement in the Arctic are still few. This can be explained by the fact that studies devoted to the resettlement of the population do not distinguish the Arctic part of the territory, but consider the Far North as a whole.

The object of this research is the Arctic as a special strategic geographic zone of circumpolar and polar regions and territories that have priority in the system of global and national interests of the country. The list of overland territories of the Arctic zone of the Russian Federation is determined by the Decrees of the Russian President in 2014 and in 2017 [4]. The Murmansk region, Nenets Autonomous Region, Chukotsky Autonomous Region, Yamalo-Nenets Autonomous Regions and the Republic of Karelia are fully included in the Arctic zone of the Russian Federation. The Republic of Sakha (Yakutia), the Krasnoyarsk Territory, the 
Arkhangelsk Region, the Komi Republic are partially included in the Arctic zone.

The main purpose of this article is to fill the existing gap in the study of the population problems and the resettlement in the Russian Arctic. The research interest is aimed at studying the population trends, assessing the population in urban settlements and the place of cities in the system of resettlement of the Russian Arctic for the future.

The purpose of this article is to show the features of the urban population resettlement in the Arctic zone of the Russian Federation. The subject is the location of the urban population on the Arctic land territories. The research interest is aimed at studying trends in population dynamics, evaluation of the population of urban settlements and the role of cities in the system of resettlement of the Russian Arctic. The demographic problems, which are also important for improving the settlement system of the North and the Arctic examined in detail in [5] [6] [7] [8].

The information base was the materials of the Federal State Statistics Service from 1959 to 2017. The statistics given in this article do not take into account changes in the land territories of the Arctic zone according the Decree of the Russian President in 2017 [9]. Also the statistical data for Russia as a whole are given without taking into account the Republic of Crimea and the city of Sevastopol.

\section{POPULATION RESETTLEMENT: CONCEPTS AND APPROACHES}

The population resettlement is the process of distribution and redistribution of the population across the territory, and the result of this process is the network of settlements. The population resettlement includes its placement, functional territorial interrelationships between populated areas and population migration as a way of implementing interterritorial connections.

Population settlement is a complex of socio-economic process that reflects many aspects of society's life. The population distribution is influenced by three groups of factors: (1) socio-economic (level of economic development, social infrastructure, sectoral structure of the economy, transport accessibility); (2) natural (climate, terrain, soil, etc.); (3) demographic (the level of natural reproduction of the population, the intensity of migration links).

The development of industrial civilization, structural changes in the economy reduce the direct influence of natural factors on population distribution, lead to a change in the structure of the needs of the population and increase the tendency for its concentration in certain regions and large cities. In turn, regional differences in the modes of population reproduction also significantly change the pattern of settlement. With the development of civilization, the role of migration in the formation of the main centers of population settlement grew. According to Martin S., Killorin M., Colt S.[10] migration out of small rural villages is a long-term trend in territories of the Arctic. For northern places, the complications involve high net migration people either pulled in by resource and industrial development, or pushed away as resources are depleted or better opportunities open up elsewhere[11].

Thus, the population resettlement is the process of placing people on inhabited territory: the distribution of settlements across the territory, people by settlements and, finally, the very settlement of them in populated areas. That is, the key concept of population settlement is the settlement of people, their place of residence. Resettlement is closely related to the interests and needs of production and is due to the location of production and social organizations in a given territory. However, it is not the true that the pattern of resettlement is due only to production. This dependence is historically changeable. At present, the point of view that the location of production should take into account the specific features of the vital activity of the population of a particular territory, the quality of labor and demographic potentials is gaining increasing understanding. In the case of the Arctic zone, the interests of the indigenous population must also be taken into account.

With the development of the northern and arctic territories, two forms of resettlement have historically developed: tape resettlement and focal resettlement. Tape settlement is characterized by locating settlements along rivers, railways and highways. This type of resettlement was characteristic before and during the initial period of industrial development of the Russian North. In case of focal population resettlement, the presence of deposits of hard coal, oil and gas, non-ferrous and rare metals, forest and other types of natural raw materials is the basis. This form of settlement is the main one since the industrial development of the northern and Arctic territories of Russia. The indigenous population lived either along rivers or roamed the tundra without being tied to a particular place of residence. Therefore, we can state that the basis for the formation of cities and workers' settlements in the North and in the Arctic was and is production, or rather - the areas of occurrence of scarce mineral resources for the country.

It should be noted that approaches to the formation of cities were more stringent than to urban settlements. Their creation was determined, first of all, by economic specialization and prospects for further development of the region, which depended, first of all, on the city-forming industry. In the early 1980's the following types of cities were proposed in quantitative terms: support for 300 thousand people, basic for 80-150 thousand inhabitants, industrial for 15-30 thousand, watch and expedition settlements [12, p. 11]. In a later period and today there is no single point of view about the most optimal size of the city in the North and the Arctic.

Population resettlement as a process can be quantified based on the following indicators: population density; share of urban population; the urban population of urban settlements; the population of rural settlements; dynamics of the population (total, urban and rural). 


\section{DYNAMICS OF THE POPULATION OF THE ARCTIC ZONE OF THE RUSSIAN FEDERATION}

The population of the land territories of the Russian Arctic zone was just 2 million people, or 1,6\% of the Russian population in 2017. Almost 90\% live in towns and urbantype settlements. Three Arctic regions have a population of more than 500 thousand people: the Murmansk Region, the Arkhangelsk Region and the Yamalo-Nenets Autonomous District.
From 1989 to 2017 the population of the Russian Arctic zone decreased by 1 million people. The urban population decreased by 881 thousand people. There was a decrease in the population in seven Russian regions of the Arctic zone.Only in the Yamalo-Nenets Autonomous District the population, including the urban population, has increased. Regions included in the Russian Arctic zone are highly urbanized. The share of urban population is from $83 \%$ to $99,4 \%$. Two regions are poorly urbanized: the Republic of Sakha $(50,5 \%)$ and the Chukotka Autonomous District (70\%) in "Table I".

TABLE I. The Number of POPUlAtion OF THE OF THE RUSSIAN ARCTIC ZONE From 1989 TO 2017

\begin{tabular}{|c|c|c|c|c|c|c|c|c|c|}
\hline \multirow[t]{2}{*}{ Territory } & \multicolumn{3}{|c|}{$\begin{array}{l}\text { The number of population, mln } \\
\text { people }\end{array}$} & \multicolumn{3}{|c|}{$\begin{array}{l}\text { Including the urban population, mln } \\
\text { people }\end{array}$} & \multicolumn{3}{|c|}{ Including the urban population, $\%$} \\
\hline & 1989 & 2010 & 2017 & 1989 & 2010 & 2017 & 1989 & 2010 & 2017 \\
\hline The Russian Federation & 147,0 & 142,8 & 144,4 & 107,9 & 105,3 & 107,6 & 73,4 & 73,7 & 74,5 \\
\hline The Russian Arctic zone & 3,3 & 2,4 & 2,3 & 3,0 & 2,17 & 2,1 & 88,5 & 89,5 & 89,3 \\
\hline The KomiRepublic & 0,2 & 0,1 & 0,08 & 0,2 & 0,1 & 0,08 & 99,3 & 99,4 & 99,4 \\
\hline The Sakha (Yakutia) Republic & 0,08 & 0,03 & 0,03 & 0,06 & 0,01 & 0,01 & 76,1 & 51,7 & 50,5 \\
\hline KrasnoyarskRegion & 0,3 & 0,2 & 0,2 & 0,34 & 0,21 & 0,2 & 89,7 & 89,9 & 90,4 \\
\hline Arkhangelsk Region & 0,8 & 0,6 & 0,6 & 0,7 & 0,6 & 0,6 & 92,7 & 92,5 & 92,8 \\
\hline Murmansk Region & 1,1 & 0,8 & 0,7 & 1,07 & 0,7 & 0,7 & 92,0 & 92,8 & 92,4 \\
\hline NenetsAutonomousArea & 0,05 & 0,04 & 0,04 & 0,03 & 0,03 & 0,03 & 63,7 & 67,8 & 72,4 \\
\hline ChukotkaAutonomousArea & 0,1 & 0,05 & 0,05 & 0,1 & 0,03 & 0,03 & 72,6 & 64,8 & 70,0 \\
\hline $\begin{array}{l}\text { Yamalo- } \\
\text { NenetsAutonomousArea }\end{array}$ & 0,4 & 0,5 & 0,5 & 0,3 & 0,4 & 0,4 & 77,9 & 84,7 & 83,7 \\
\hline
\end{tabular}

\section{Cities OF THE RUSSIAN ARCTIC}

From 1979 to 1989 , the population of the cities of the land territories of the Arctic increased by 623 thousand people. In subsequent years, the population of cities was constantly reduced due to migration. Between 1989 and 2017, the population decreased by 505 thousand people. At the same time, it can be noted that at the beginning of 2017 the population of the cities of the Arctic zone is still larger than the population in 1979 by 118 thousand people.

The number of cities was constantly increasing. In 1979 in the Russian Arctic zone there were 26 cities and at the beginning of 2017 there were 37 cities. The prevailing cities are cities with a population more than 50 thousand people 28 cities out of a total number. There are two cities with a population of more than 250 thousand people in "Table II".

TABLE II. DistribUtion OF CITIES IN THE RUSSIAN ARCTIC ZONE

\begin{tabular}{|c|c|c|c|c|c|}
\hline Indicators & 1979 & 1989 & 2002 & 2010 & 2017 \\
\hline Dynamics of the urban population in the Russian Arctic zone, \% & 100 & 133,6 & 113,3 & $\mathbf{1 0 7 , 8}$ & 106,3 \\
\hline $\begin{array}{l}\text { Numberofcities } \\
\text { with the population }\end{array}$ & 26 & 30 & 38 & 37 & 37 \\
\hline lessthan 5000 people & 1 & 1 & 1 & 3 & 4 \\
\hline 5 000-9 999people & & & 4 & 2 & 2 \\
\hline 10 000-19 999people & 5 & 4 & 9 & 9 & 9 \\
\hline 20 000-49 999people & 12 & 12 & 13 & 14 & 13 \\
\hline 50 000-99 999people & 3 & 8 & 7 & 3 & 3 \\
\hline 100 000-249 999people & 3 & 2 & 2 & 4 & 4 \\
\hline 250000 peopleand more & 2 & 3 & 2 & 2 & 2 \\
\hline $\begin{array}{l}\text { Dynamics of the average urban population in the Russian Arctic } \\
\text { zone, } \%\end{array}$ & 100 & 115,8 & 77,5 & 75,7 & 74,7 \\
\hline $\begin{array}{l}\text { Dynamics of the average urban population in the Russian } \\
\text { Federation, } \%\end{array}$ & 100 & 109,6 & 105,2 & 106,7 & 110,6 \\
\hline
\end{tabular}

The average urban population in the Arctic zone decreased every year and decreased by $26 \%$ in 2017 compared to 1979. In Russian Federation as a whole, the average urban population was consistently was constantly growing and in 2017 increased by $10 \%$ compared to 1979 in "Table II". The high population of Arctic cities is preserved due to the fact that the bulk of the population of cities $(79 \%)$ lives in cities with a population of more than 50 thousand people in "Table III". 
TABLE III. Distribution of the URban Population of the RUSSIAN ARCTIC Zone

\begin{tabular}{|c|c|c|c|c|c|c|c|c|c|c|}
\hline \multirow[t]{2}{*}{$\begin{array}{l}\text { Number of cities with the } \\
\text { population: }\end{array}$} & \multicolumn{5}{|c|}{$\begin{array}{l}\text { Specific weight of the urban population in the } \\
\text { Arctic zone of Russia, \% }\end{array}$} & \multicolumn{5}{|c|}{$\begin{array}{l}\text { Specific weight of the urban population in the } \\
\text { Russian Federation, \% }\end{array}$} \\
\hline & 1979 & 1989 & 2002 & 2010 & 2017 & 1979 & 1989 & 2002 & 2010 & 2017 \\
\hline Less than 5000 people & 0,3 & 0,2 & 0,2 & 0,5 & 0,7 & 0,1 & 0,1 & 0,1 & 0,2 & 0,1 \\
\hline $5000-9999$ people & & & 1,2 & 0,6 & 0,8 & 0,8 & 0,7 & 0,8 & 0,9 & 1,1 \\
\hline $10000-19999$ people & 3,9 & 2,7 & 6,3 & 6,3 & 6,8 & 4,3 & 3,8 & 4,3 & 3,9 & 3,6 \\
\hline $20000-49999$ people & 19 & 15,6 & 19,2 & 21,6 & 20,7 & 13,2 & 12,3 & 12,1 & 11,9 & 10,9 \\
\hline $50000-99999$ people & 8,9 & 23,4 & 24,1 & 9 & 8,4 & 11,2 & 11,8 & 11,6 & 11,1 & 10,5 \\
\hline 100 000-249 999 people & 26,5 & 11,9 & 16 & 29,2 & 29,6 & 15,6 & 13,8 & 14,4 & 14,5 & 13,8 \\
\hline 250000 people and more & 41,4 & 46,2 & 33 & 32,8 & 33 & 54,8 & 57,5 & 56,7 & 57,5 & 60 \\
\hline Total & 100 & 100 & 100 & 100 & 100 & 100 & 100 & 100 & 100 & 100 \\
\hline
\end{tabular}

A special status in the resettlement network is occupied by cities with a population of more than 100 thousand people, classified as large. There were 166 such cities in Russia on January 1, 2017, of which six are located in the Arctic zone. The proportion of inhabitants of the Russian Arctic living in cities with a population of more than 100 thousand people decreased by 5\% in 2017 compared to 1979.

The small number of cities and significant distances between them lead to low territorial mobility of the population, slow modernization of the way of life and much worse adaptation to social and economic changes in vast interurban areas. This contributed to the consolidation of the tendency to increase spatial unevenness of resettlement at all territorial levels. One of the most negative results of this trend is the reduction of the developed space and, first of all, in the peripheral territories. Objective and subjective factors of vital activity of the population of the Arctic zone create difficulties in their adaptation, predetermine the preconditions for maintaining high migration turnover and low survival rates.

In order to improve the existing system of population resettlement in the Arctic zone of Russia, it is necessary to determine the concept of development of urban settlements in the Arctic [13]. In modern socio-economic conditions, even large cities are not able to develop independently to a form that presupposes self-sufficiency. The modern city in terms of its capabilities no longer corresponds to the tasks of development, since it is not self-sufficient, inefficient and irrational. An isolated city without a thought-out concept of development is unlikely to become a unit of development. It seems that such a unit of development can become a region, and the city can become its core. At the same time, the region should have the opportunity to launch development programs.

\section{CONClusion}

Thus, it can be concluded that the resettlement theme of the Arctic zone of Russia requires new, deeper research at the interdisciplinary level. On the one hand, it is necessary to consolidate populated areas, develop a city network, give new life to rural settlements, and on the other hand, it is necessary to develop the Russian Arctic, because it's an outpost between the mainland and neighboring countries.

Approaches to the socio-economic development of the cities of the Russiat Arctic zone should depend on the stage of formation and the performed functions. It's necessary to focus on the multifunctional development of the cities of the Arctic regions. There is a real basis for ensuring full and most rational employment of the population in the near future. It is necessary to move to a settlement system that includes the creation of a multifunctional city that performs administrative, cultural, transportation and other functions, and a network of shift camps with a variable population composition that have a full range of personal services and comfortable living conditions. Particular attention should be paid to the rational population distribution of Arctic cities and rural settlements, the demographic and sociological aspects of the organization of work on a rotational basis, on the expediency of training professional personnel in educational institutions located in the Russian Arctic zone.

\section{REFERENCES}

[1] V.V. Fauzer, G.N. Fauzer, I.G. Nazarova, G.V. Korshunov. Tendencies and prospects of social and economic development of the northern regions of Russia. Moscow: Ekon-Inform, 2012. 311 p.

[2] V.V. Fauzer, T.S. Lytkina, G.N. Fauzer. Demographic and migration processes in the Russian North: 1980-2000. Syktyvkar: Publishing House of Syktyvkar State University, 2016. - 168 p.

[3] Decree of the President of the Russian Federation «On Amending the Decree of the President of the Russian Federation № 296 «About the land territories of the Arctic Zone of the Russian Federation» № 287. URL: http: // kremlin. com / acts / bank / 42021. Accessed June 03, 2017.

[4] V. Lexin, B. Porphyriev. The new arrangement of the Arctic: the challenge and the social and economic resource of the Russia's future // Problems of the theory and practice of management. - 2015. - №6. pp. 54-60.

[5] A.L. Sinitsa. The demographic development of the regions of the Russian Arctic zone in 2010-2014. // Arctic: ecology and economics. - 2016. - №1. - pp. 18-27.

[6] A.E. Gorodetsky, V.V. Ivanov, B.N. Filin. Legal and methodological issues of strategic planning of development of the Arctic regions of Russia // Arctic: ecology and economy. - 2014. - № 4 (16). - pp. 413 .

[7] D.Yu. Rudenko. Analysis of demographic processes in the Russian Arctic // WORLD (Modernization. Innovation. Development). - 2015 T. 6.- № 4. - pp. 51-57.

[8] Decree of the President of the Russian Federation «About the land territories of the Arctic Zone of the Russian Federation» № 287. URL:http://kremlin.ru/acts/bank/38377. Accessed June 03, 2017.

[9] S. Martin, M. Killorin, S. Colt. Fuel costs, migration, and community viability. Anchorage, AK: Institute of Social and Economic Research. 2008. URL: https: //scholarworks.alaska.edu/handle/11122/4429. Accessed September 21, 2017. 
[10] R.O. Rasmussen (Ed.). Megatrends. Copenhagen: Nordic Council of Ministers.2011 URL:http:

//www.nordregio.se/en/Publications/Publications-2011/Megatrends/. Accessed September 21, 2017.

[11] V.K. Sveshnikov. Urban planning problems of the North. - Leningrad, 1971. - pp. 5-19.

[12] T.S. Lytkina. Social potential of the northern city: from ignoring to recognition // Journal of Sociology and Social Anthropology. - 2014. - T. XVII.- № 3. - pp. 33-47.

[13] M.A. Bayandin, G.D. Bayandina. Formation and development of the city at the stage of modernization of the economy // Modernization of Russian regions' economy: problems, reference points and factors of development. - Tyumen: Tyumen State Oil and Gas University, 2011. - pp. 35-40. 